\title{
TITLE
}

\section{Role of soil properties in sewage sludge toxicity to soil collembolans}

\section{AUTHORS}

Xavier Domene, Joan Colón, Maria Vittoria Uras, Rebeca Izquierdo, Anna Àvila, Josep M. Alcañiz

${ }^{1}$ Centre for Ecological Research and Forestry Applications (CREAF)

${ }^{2}$ Unitat d'Ecologia, Departament de Biologia Animal, Vegetal i Ecologia, Facultat de Ciències i Biociències, Universitat Autònoma de Barcelona, 08193 Cerdanyola del Vallès, Barcelona, Spain.

\begin{abstract}
Soil properties are one of the most important factors explaining the different toxicity results found in different soils. Although there is knowledge about the role of soil properties on the toxicity of individual chemicals, not much is known about its relevance for sewage sludge amendments. In particular little is known about the effect of soil properties on the toxicity modulation of these complex wastes. In addition, in most studies on sewage sludges the identity of the main substances linked to the toxicity and the influence of soil properties on their bioavailability remains unknown.

In this study, the toxicity of a sewage sludge to the soil collembolan Folsomia candida was assessed in nine natural soils from agricultural, grassland and woodland sites, together with the OECD soil. Correlations between the relative toxicity of sludge for collembolans in the different soils and their physical and chemical soil properties were assessed in order to identify the main compounds responsible for the effects observed. Furthermore, the relationships between the toxic effects to collembolans and water-soluble ions released by sludge, $\mathrm{pH}$ and electric conductivity were also assessed, together with the modulating effects of soil properties.
\end{abstract}


Sludge toxicity was directly linked to the water extractable ammonium, which explained most of the mortality of the collembolans, and part of the inhibition of reproduction. For the last endpoint, nitrite also contributed significantly to the inhibition observed. The varied levels in water extractable ammonium in the different soils at equal dosages seem to be, in turn, modulated by some soil properties. Higher organic carbon contents were associated with lower toxicity of sludge, both for survival and reproduction, probably related to its higher ammonium sorption capacity. In addition, for reproduction, increasing the $\mathrm{C} / \mathrm{N}$ ratio and $\mathrm{pH}$ appeared to increase the toxicity, probably due to both the greater difficultly in nitrification and the known unsuitability of alkaline soils for this species.

KEYWORDS: sewage sludge toxicity, collembolans, soil properties, soluble ions, ammonium, organic matter.

\section{MAIN TEXT}

\section{INTRODUCTION}

The bioavailability of pollutants for soil organisms is broadly due to the sorption equilibrium between the soil solid-phase and the pore water, and more precisely due to pollutant concentrations in soil pore-water, which is the main exposure route for soil-inhabiting animals (Smit and Van Gestel 1998). As soil pore water concentration is mediated by sorption to soil which in turn depends on the nature and content of clay and humus, the bioavailability and toxicity of any pollutant is at least partly influenced by soil properties. Such influence has been widely studied for individual pollutants (Lock and Janssen 2001c, Sverdrup et al. 2001, Amorim et al. 2005a, Amorim et al. 2005b), but studies dealing with the influence of soil properties on the toxicity of complex mixtures of pollutants contained in organic matrices are scarce (McBride et al. 2004). 
In previous studies, we have found that the acute toxicity of different sludges for some soil and aquatic organisms was mainly correlated with water soluble compounds (Domene et al. 2008,

Ramírez et al. 2008). In addition, the results indicated that the toxicity of the different sludges was positively correlated with several physicochemical parameters reflecting a high labile organic matter content (stability degree, total and hydrolysable nitrogen and ammonium). Despite the varied pollutant burden of the wastes tested, the impact of these physicochemical parameters overcame any influence of the pollutant burden. These results suggested that ammonium or other water soluble compounds released by wastes containing high labile organic matter content might be the main explanation for the acute toxic effects observed. However, these studies, carried out entirely using OECD artificial soil (OECD 1984), did not allow us to assess the influence of soil properties on the bioavailability of these toxics.

In this study, the toxicity of sewage sludge for collembolans was assessed in nine natural soils from agricultural, grassland and woodland sites, together with tests using OECD artificial soil. The main objectives of this work were (1) to identify the main water soluble compounds explaining the toxicity of a single sewage sludge in a wide variety of soils; and (2) to assess the influence of soil properties on the modulation of toxicity for the collembolan Folsomia candida.

\section{METHODS}

\subsection{Soils}

All soils were collected from different localities in Catalonia (NE Spain), and came from agricultural land, grassland, and woodland. In agricultural soils, agrochemical treatments were low or absent. Soils were sieved to $5 \mathrm{~mm}$, air-dried, and defaunated alternating two freezingthawing cycles which consisted of placing soils in the freezer $\left(-20^{\circ} \mathrm{C}\right)$ for 4 days followed by 4 days at room temperature. OECD artificial soil was also prepared according to the OECD

Guideline 207 (1984). The inclusion of OECD soil was for comparative purposes and because of its usual use in soil ecotoxicology studies. The main properties of the selected soils are 
reported in Table 1, together with their heavy metals concentrations, determined according to the ISO Guideline 11885 (1996), in order to detect any concentration over those expected from natural sources.

\subsection{Sewage sludge}

To perform the bioassays, a thermally-dried sewage sludge from Banyoles WWTP (Girona, Spain) was selected. This organic waste was obtained through thermal drying of an aerobically digested and dewatered sludge. Drying was carried out in a heated rotary cylinder with an injected hot air stream at temperatures of around $130-150^{\circ} \mathrm{C}$ for 45 minutes. Just before the analysis, the sludge was again dried at $60^{\circ} \mathrm{C}$ for $48 \mathrm{~h}$ to guarantee its dryness, and sieved to 2 $\mathrm{mm}$ to ensure the homogeneity and accuracy of the test concentrations. The final product was used for both the characterization of the sludge and for the preparation of the soil-mixtures of the bioassays.

The physico-chemical properties, heavy metal and main organic pollutant contents of the sludge are recorded in Table 2. Dry matter, water holding capacity, $\mathrm{pH}\left(\mathrm{pH}_{\text {soil }}\right)$, electrical conductivity, total nitrogen, and organic matter were measured according to EN 12880 (2000), ISO 11267 (1999), EN 13037 (1999), EN 13038 (1999), EN 13342 (2000) and EN 12879 (2000), respectively. Non-hydrolyzable organic matter and non-hydrolyzable nitrogen levels were measured as the percentage of organic matter and nitrogen remaining in the sample residue after acid hydrolysis, as described in Rovira and Vallejo (2002). This treatment removes the more labile fraction of an organic substrate, mainly consisting of polysaccharides and proteins. Hydrolyzable nitrogen was estimated by subtracting the content of non-hydrolyzable nitrogen from the total nitrogen content. $\mathrm{N}-\mathrm{NH}_{4}$ was measured in the distillates obtained from a fresh sample suspension. Elemental analysis of $\mathrm{P}, \mathrm{K}, \mathrm{Cd}, \mathrm{Cr}, \mathrm{Cu}, \mathrm{Hg}, \mathrm{Ni}, \mathrm{Pb}$ and $\mathrm{Zn}$ was carried out by ICP-MS according to ISO 11885 (1996). Polychlorinated dibenzodioxins and dibenzofuranes (PCDD/F) were measured with HRGC-HRMS, polychlorinated biphenyls (PCB) by HRGC-ECD, and di(2-ethylhexyl)phthalate (DEHP) and nonylphenols (NPE) by 
HRGC-MS. Polycyclic aromatic hydrocarbons (PAH) and linear alkylbenzene sulphonates (LAS) were determined by HPLC with fluorescence and UV detectors, respectively. Concentration values were expressed as recorded in the third draft of the Working Document on Sludge (European Communities 2000). DEHP, LAS, and PCDD/F values corresponded to total values. NPE included nonylphenol and nonylphenol ethoxylates with one or two ethoxy groups; $\mathrm{PAH}$ was the sum of acenapthene, phenanthrene, fluorene, fluoranthene, pyrene, benzo(b+j+k)-fluoranthene, benzo(a)-pyrene, benzo(ghi)-perylene, and indeno(1, 2, 3-c, d)pyrene; PCB was the sum of the polychlorinated biphenyl congeners number 28, 52, 101, 118, 138, 153 and 180.

Pollutant concentration in the sludge was below the limit values of the current legislation on sludge (Directive 86/278/EEC), with the exception of lead, which exceeded the limit value allowing its reuse in soil (50-300 $\mathrm{mg} \mathrm{kg}^{-1}$ ). NPE values were also slightly above the $50 \mathrm{mg} \mathrm{kg}^{-1}$ limit value suggested by the third draft of the new Directive on sludge draft (European

\section{Communities 2000).}

In order to relate the biological effects observed in collembolans with soil-sludge mixtures composition, we measured, at the end of the experimental period and for each soil and sludge concentration, the $\mathrm{pH}\left(\mathrm{pH}_{\text {mixtures}}\right)$, the electrical conductivity (EC), and certain soluble anions and cations (chloride, nitrate, nitrite, phosphate, sulphate, and ammonium). Three replicates per dosage and soil were used for the analysis.

Both the $\mathrm{pH}$ and EC were measured in an aqueous extract, consisting of a soil-water 1:5 mixture $(\mathrm{w} / \mathrm{v})$ mixed in a vertical agitator (120 revolution per minute) for 1 hour.

The anionic content (chloride, nitrate, nitrite, phosphate, sulphate) was measured in aqueous extracts consisting of a soil-water 1:10 mixture (w/v) prepared by mixing $5 \mathrm{~g}$ of fresh sample with $50 \mathrm{ml}$ of water for 40 minutes in a vertical agitator (around $120 \mathrm{rpm}$ ). Then, the extracts were filtered in Whatman no. 42 filters and immediately used for ionic determination by liquid chromatography using a AS4A-SC Dionex anion column on a Dionex DX-100 Ion Chromatograph (Dionex, Sunnyvale, USA). A standard solution of the following salts was 
prepared using analytical grade reagents $\left(\mathrm{NaCl}, \mathrm{KNO}_{3}, \mathrm{NaNO}_{2}, \mathrm{Na}_{2} \mathrm{HPO}_{4}\right.$ and $\left.\mathrm{K}_{2} \mathrm{SO}_{4}\right)$, containing 21.27, 55.80, 23.00, 19.19 and $36.02 \mathrm{mg} \mathrm{l}^{-1}$ of chloride, nitrate, nitrite, phosphate and sulphate, respectively.

Soluble ammonium was measured in aqueous extracts in a Büchi K-314 distillation unit (Büchi Labortechnik AG, Flawil, Switzerland) by the Kjeldahl method (Büchi Labortechnika 2002). The extracts were prepared as described previously for anions and cations, but the filtration step was replaced by a decantation stage 10 minutes after the finish of the 40 minutes mixing stage. After that, the ammonia in the decanted extract was distilled in a Kjeldahl distillation unit by alkalization $(\mathrm{NaOH} 10 \mathrm{M})$ and steam injection to the extract. The amount of decanted extract was $50 \mathrm{ml}$ in the lowest dosages $\left(\leq 4 \mathrm{~g} \mathrm{~kg}^{-1}\right)$, and $25 \mathrm{ml}$ mixed with $25 \mathrm{ml}$ of water in the remaining dosages. Around $100 \mathrm{ml}$ of distillate were then collected in an in a $250-\mathrm{mL}$ Erlenmeyer flask containing $50 \mathrm{ml}$ of $\mathrm{H}_{3} \mathrm{BO}_{3}$. Then, 12 drops of indicator solution were added (0.099 g bromocresol green and 0.066 methyl red in $100 \mathrm{~m} 1$ of ethanol 96\%), and the solution was titrated with $\mathrm{HCl} 0.005 \mathrm{M}$. The concentration of ammonia in the samples was estimated by the following expression $\left.\mathrm{NH}_{4}{ }^{+}\left(\mathrm{mg} \mathrm{kg}^{-1}\right)=\left[(\mathrm{A}-\mathrm{B}) /\left(\mathrm{C}^{*} \mathrm{M} * 1.4\right)\right)\right] / 1000$, where A corresponds to the $\mathrm{HCl}$ volume consumed in the sample, B corresponds to the volume consumed in the blank, C corresponds to the sample dry weight, and M corresponds to the $\mathrm{HCl}$ molarity. Results were expressed on the basis of soil dry weight, since the moisture of each sample was also determined.

Heavy metal contents in water extracts were not measured as their concentrations were expected to be under the detection limit, due to the low solubility of metals in sludge, and according to a previous study using different sludges, including the one used in this study (Domene et al. 2008). In addition, these water-soluble metal concentration values, even at the highest sludge dosages, were clearly below the values expected to be toxic for this and related species (Sandifer and Hopkin 1996, Pedersen and van Gestel 2001, Fountain and Hopkin 2005). 


\subsection{Test organism}

The soil collembolan Folsomia candida was used as the test organism. The effects of pollutants on this species are considered to be representative for collembolans, a group present in all types of soils and a key group in soil ecosystems. Collembolans are exposed to pollutants via the epidermis, ventral tube via water, or gut via food; that being said, the main exposure route is not clear (Fountain and Hopkin 2004a). Individuals were bred in a moistened mixture made of plaster of Paris and charcoal (9:1, w/w) and fed weekly with granulated dry yeast. Cultures were maintained in the dark at $21 \pm 1{ }^{\circ} \mathrm{C}$. For the assays, individuals of synchronized age (10 to 12 days) were used, produced as described in ISO 11267 (1999).

\subsection{Test performance}

The water content in each soil was adjusted to around 50\% of its maximum water holding capacity (WHC). For soils with higher silt and clay content, this moisture level was difficult to reach without losing the crumbly texture, as soil easily takes on a doughy structure. This difficulty was overcome by the addition of small quantities of water over several hours.

Eight test concentrations were prepared for the assays: 1, 2, 4, 8, 16.1, 32.7, 67.3 and $144 \mathrm{~g} \mathrm{~kg}^{-1}$ (w/w) of sludge mixed with each of the soils, together with controls consisting of soil without sludge. For each sludge concentration and control, five replicates were prepared, comprising 20 g (dry weight) of wet soil-waste mixture in sealed 150-ml polyethylene flasks.

As indicated in the ISO Guideline 11267 (1999), ten individuals 10 to 12 days-old were added to each replicate, together with $5 \mathrm{mg}$ of granulated yeast. Food was again provided after two weeks. Flasks were sealed to avoid water losses but aerated twice a week. The test lasted 28 days and was carried out in the dark and at $21 \pm 1^{\circ} \mathrm{C}$.

At the end of the test, the flask content was poured into a bigger container and flooded with water in order to float the adults and juveniles present in the soil. After adding a few drops of a dark dye and gently stirring the soil, a picture of the surface was taken. Adults and juveniles 
were counted from these pictures with image treatment software ImageTool 3.0 (UTHSCSA, San Antonio, USA).

\subsection{Data treatment}

In order to compare the toxicity obtained in the different soils, we expressed the number of surviving individuals and juveniles as a percentage of the mean values of the survival or reproduction rates of their respective controls. Then, for each soil, we estimated the lethal concentration which reduced survival by 50\% (LC50) and the effective concentration which reduced the reproduction by 50\% (EC50), together with their 95\% confidence intervals using the most suitable regression model in each case (exponential, Gompertz, hormesis, and logistic) according to the criteria indicated in Stephenson et al. (2000) and using Statistica 6.0 (StatSoft Inc., Tulsa, USA).

In order to relate the toxic effects observed to the water soluble ions released by sludge and the soil properties, we constructed regression models through generalized linear models (GLM) using Brodgar 2.5.2 (Highland Statistics Ltd, Newburgh, UK). In each model, the response variable corresponded to the inhibition percentage of the biological endpoint assessed (survival or reproduction), expressed in comparison to the number of adults and juveniles present in controls. As explanatory variables we included the sludge dosage, $\mathrm{pH}$, electrical conductivity $\left(\mu \mathrm{S} \mathrm{m} \mathrm{m}^{-1}\right)$ and water-soluble ions in soil-sludge mixtures $\left(\mathrm{mg} \mathrm{kg}^{-1}\right)$, in order to identify any significant contribution to the toxicity observed. In addition, the soil properties of each of the soils used in the mixture were also added as explanatory variables (Table 1). The inclusion of the percentage survival and reproduction as a response variable instead of the absolute number of surviving adults and juveniles was due to the fact that we only wanted to take into account the indirect effects of soil properties on toxicity through their effects on bioavailability, discarding any direct effects on the test species outcome related to their ecological preferences, known to be strongly influenced by soil properties (Jänsch et al. 2005). 
The explanatory variables showing high autocorrelation were not used for the model construction (those showing variance inflation factors (VIF) over 10). This is why sludge concentration and electrical conductivity of the soil-sludge mixtures, together with sand content and total nitrogen in soils, were discarded for the GLM analysis.

The explanatory variables retained were used for the model construction assuming a Poisson distribution and using the logarithm as link function. The reason for assuming a Poisson distribution was because our data resemble counts more than percentages, since inhibition percentages were over 100 at low sludge dosages. When overdispersion was clearly different to 1, a quasi-Poisson distribution was assumed. The model containing the variables with the best adjustment to our data (lower Akaike Information Criteria value AIC) was obtained by an automated backwards-forwards selection procedure. The suitability of the model was evaluated by assessing the homogeneity of the residuals (looking to the residuals versus fitted values plot), and their normality (by means of a normal Q-Q-plot).

Heavy metal content in soils was not included in the analysis, as they were expected not to influence the toxicity results, since their values were below those expected to affect survival (Crommentuijn et al. 1993, Greenslade and Vaughan 2003, Bongers et al. 2004, Lock and Janssen 2001b) and reproduction in this species (Lock and Janssen 2001a, Lock and Janssen 2002a, Lock and Janssen 2002b, Fountain and Hopkin 2005).

\section{RESULTS}

\subsection{Sludge toxicity in the different soils}

Toxicity results for survival (LC50) and reproduction (EC50) are recorded in Table 3. The performance of collembolans in test soils fulfilled the validity criteria of ISO 11267 (1999), as mean survival in controls was always over $80 \%$, and more than 100 juveniles were produced per replicate (ranging from 187 juveniles in CAM to 938 in PRA2). The coefficient of variation was 
also below 30\% in all soils, with the exception of VALL (36\%) and STA (46\%). Despite this, we assumed that the results from these two soils were suitable for the purposes of this study.

The sludge toxicity was relatively high, as LC50 were always below $100 \mathrm{~g} \mathrm{~kg}^{-1}$, and EC50 were below $50 \mathrm{~g} \mathrm{~kg}^{-1}$ in all soils. When the different natural soils were compared for toxicity, it is worth noting that the lowest toxicity for survival and reproduction was always observed in STA soil $\left(\mathrm{L} 50=92 \mathrm{~g} \mathrm{~kg}^{-1}, \mathrm{EC} 50=74 \mathrm{~g} \mathrm{~kg}^{-1}\right)$, while the highest was found in GAN soil (LC50 =21 g

$\mathrm{kg}^{-1}$, EC50 $\left.=5 \mathrm{~g} \mathrm{~kg}^{-1}\right)$. On the other hand, it is worth noting that LC50 in OECD artificial soil was slightly below but not far from the median value in the whole set of soils (41.1 $\left.\mathrm{g} \mathrm{kg}^{-1}\right)$. On the contrary, EC50 was the lowest in OECD soil, far from the median value $\left(14.5 \mathrm{~g} \mathrm{~kg}^{-1}\right)$.

\subsection{Toxicity and soluble ion composition and the influence of soil properties}

The $\mathrm{pH}$ and electrical conductivity in the different soil-sludge mixtures are shown in Figure 1, while the water soluble ionic content is shown in Figure 2. Concerning pH, it was shown that at the end of the experiment, the addition of increasing quantities of sludge generally increased $\mathrm{pH}$, as shown by the positive correlation between $\mathrm{pH}$ and sludge dosage (Table 4). This is especially true for some neutral and basic soils that reached very alkaline $\mathrm{pH}$ (CAM, PRA2, RIU), but also for the slightly acidic soils, where the pH shifted towards neutral (COLL, OECD, STA, VALL). The main explanation seems to be the water extractable ammonium content, which correlated positively with pH (Table 4). However, a contrasting pattern was observed in some alkaline soils (GAN, GRA, POR), where the pH moved towards neutral.

Regarding the electrical conductivity, a constant increase was observed with sludge dosage in all the soils, with no clear differences in the trend between soils. The increase in EC was also positively correlated with $\mathrm{pH}$, ammonium, chloride, phosphate and sulphate (Table 4), but not with nitrite and nitrate.

Regarding water-soluble ionic content in the mixtures, we observed clearly different patterns in the different soils. Chloride, phosphate and sulphate increased steadily with increasing sludge dosages in all the soils. On the contrary the behavior of ammonium, nitrate and nitrite was 
coupled in a pattern that changed depending on the soil. Most soils showed a nitrate peak at intermediate dosages that was linked to an ammonium peak at the higher dosages (CAM, GAN, GRA, POR, PRA2 and RIU). This suggests nitrification inhibition in these soils, at concentrations higher than 8 g sludge $\mathrm{kg}^{-1}$ (GAN, GRA and POR) and over $16 \mathrm{~g} \mathrm{~kg}^{-1}$ (CAM, PRA2 and RIU). However, this trend was not observed in the remaining soils (COLL, OECD, STA and VALL), with no nitrate peaks and with a sustained increase in ammonium concentrations with sludge dosage. Nitrite concentrations were generally low, and high concentrations were only observed in GRA soil, with a nitrite peak at intermediate dosages.

As found for $\mathrm{pH}$ and $\mathrm{EC}$, ionic content in soil-sludge mixtures was positively correlated with sludge dosage, as shown by Pearson's positive correlations (Table 4), indicating the direct contribution of sludge to these properties. The only exception is nitrite which did not correlate with sludge dosage. Concerning correlations between ions, nitrite did not show correlations with other compounds, neither did nitrate with the exception of its negative correlation with ammonium. Chloride, phosphate and sulphate were positively correlated.

The GLM both for survival and reproduction inhibition were carried out assuming a quasiPoisson distribution and the logarithm as link function. The selection of quasi-Poisson was due to the unacceptably high overdispersion in both endpoints when a Poisson distribution was assumed.

The model derived for percentage survival was significantly and negatively influenced by water soluble ammonium and phosphate, and positively affected by the organic carbon content. Though the contribution of soluble phosphate was not significant, this parameter contributed to the model with the best fit (Table 5). The model consisted of the equation: survival $(\%)=\mathrm{e}^{\wedge}\left(4.5998336+\left(-0.0016995 * \mathrm{NH}_{4}{ }^{+}\right)+\left(-0.0007183 * \mathrm{PO}_{4}{ }^{3-}\right)+(0.0356326 * \mathrm{C}), \quad\right.$ where ion concentrations are expressed as $\mathrm{mg} \mathrm{kg}^{-1}$ and organic carbon as a percentage. The coefficient of determination for the model $\left(\mathrm{R}^{2}=[\right.$ (null deviance-residual deviance)/(null deviance) $]$ ) was 0.723 , meaning that the model was able to explain $72.3 \%$ of the variance in the number of adults present in soil-sludge mixtures. 
Regarding the model derived for percentage reproduction, it included the negative influence of ammonium, nitrite, phosphate, soil $\mathrm{pH}$ and $\mathrm{C} / \mathrm{N}$ ratio, and the positive influence of organic carbon. All these parameters were significant, and expressed as $\mathrm{mg} \mathrm{kg}^{-1}$ for ion content and as a percentage for organic carbon (Table 5). The model was described by the equation: reproduction $(\%)=\mathrm{e}^{\wedge}\left(5.7320865+\left(-0.0049192 * \mathrm{NH}_{4}{ }^{+}\right)+\left(-0.002664 * \mathrm{NO}_{2}{ }^{2-}\right)+\left(-0.0045712 * \mathrm{PO}_{4}{ }^{3-}\right.\right.$ )$+\left(-0.1298969 * \mathrm{pH}_{\text {soil }}\right)+(-0.0070324 * \mathrm{CN})+(0.0495936 * \mathrm{C})$, where the ion content is expressed as $\mathrm{mg} \mathrm{kg}{ }^{-1}$ and organic carbon as a percentage. The model explained $71.7 \%$ of the variance.

\section{DISCUSSION}

\subsection{Soil properties and bioavailability}

Pollutants toxicity may differ depending on the test organism sensitivity, but also depending on the soil properties which modulate their bioavailability (Lock and Janssen 2001c, Sverdrup et al. 2001, Amorim et al. 2005a, Amorim et al. 2005b). Results from our study are consistent with the last point, since differences in the toxicity values (LC/EC50) were found in different soils for the same sludge. Differences in toxicity among soils were four-fold for mortality and seventeen-fold for reproduction. When only agricultural soils were taken in to account, the variation was lower but still considerable, with close to a three-fold impact for mortality and reproduction.

Bioavailability is mainly explained by the sorption equilibrium between soil solid-phase and pore water. This is why toxicity differences between soils for a given pollutant burden are primarily due to their concentrations in soil pore-water, the main exposure route to chemicals for soil-inhabiting animals (Smit and Van Gestel 1998). In the specific case of collembolans, it has been suggested that pollutant uptake is associated more directly to the soil solid-phase, in comparison to the soft-bodied oligochaeta species and plants, which are more strongly influenced by pore-water characteristics (Vijver et al. 2001). However, several studies have indicated that pore-water pollutant concentrations are the main explanatory uptake route for 
collembolans (Martikainen and Krogh 1999, Lock and Janssen 2003). On the other hand, other uptake processes are likely to occur simultaneously, as is the case of this species, which has been shown to ingest sewage sludge during bioassays (Domene et al. 2007a). The results from our study indicate the importance of pore-water uptake in collembolans for the toxicity of sludge, since the variation in water extractable compounds, namely ammonium, was the main factor which explained the differences in toxicity observed.

\subsection{Toxicity and correlation with soil properties}

In the context of deriving general rules to extrapolate toxicity data between soils, it is difficult to establish cause-and-effect relationships between soil properties and a chemical's bioavailability, as generally soil properties are inter-correlated. Hence, for instance, CEC is generally related to $\mathrm{pH}$, as cation exchange sites of soil organic matter are $\mathrm{pH}$-dependent, but it is also related to clay and organic carbon content, as they contain such cation-exchange sites (Dayton et al. 2006). Furthermore, for each pollutant and soil properties combination, the properties with the largest influence may differ (Van Gestel 1997, Peijnenburg et al. 1999). However, it is widely accepted that $\mathrm{pH}$, CEC, and clay and organic matter content are the most important soil parameters which affect the toxicity of pollutants (Van Gestel et al. 1995, Lock et al. 2000, Boyd and Williams 2003, Simini et al. 2004).

In this study, some of the soil properties explained significantly the toxicity values observed. More precisely, LC50 values were positively correlated with organic carbon content $(\mathrm{r}=0.672$, $\mathrm{p}=0.033)$ and total nitrogen content $(\mathrm{r}=0.728, \mathrm{p}=0.017)$. Similarly, EC50 values were mainly positively correlated with total nitrogen content $(\mathrm{r}=0.658, \mathrm{p}=0.38)$, thus indicating that the inhibition in collembolan survival and reproduction was higher in soils with lower organic matter content, since $\mathrm{C}$ and $\mathrm{N}$ contents were also correlated $(\mathrm{r}=0.828, \mathrm{p}=0.003)$. This agrees with the results of the GLM analysis, which allowed us to identify this and other soil properties together with the main soluble compounds responsible for the toxicity observed. 
Most of the soluble ions in the soil-sludge mixtures increased in concentration with increasing sludge dosages (Figure 2), with the exception of nitrite and nitrate, that were uncorrelated and inversely correlated, respectively, with sludge dosage (Table 4). Despite the fact that we lack of direct measures, these contrasting patterns in nitrogen forms suggest different microbial communities present in the different soils and/or interactive effects of these communities with soil properties. More precisely, we observed nitrification inhibition in some of the soils over $8 \mathrm{~g}$ sludge $\mathrm{kg}^{-1}$ (GAN, GRA and POR) and over $16 \mathrm{~g} \mathrm{~kg}^{-1}$ in others (CAM, PRA2 and RIU), while no inhibition was observed in the remainder (COLL, OECD, STA and VAL). The negative correlation between the water-soluble ammonium and nitrate levels shows this and demonstrates the coupled dynamics of ammonium and nitrate.

Ammonium is released with the decomposition of organic materials, which can be then biologically converted to nitrate $\left(\mathrm{NO}_{3}^{-}\right)$by the process called nitrification. This process is mainly mediated by bacteria, and it is initiated by the transient conversion and accumulation as nitrite $\left(\mathrm{NO}_{2}{ }^{-}\right)$, primarily by Nitrosomonas sp. The nitrite is quickly converted to nitrate by Nitrobacter sp. Nitrification has been shown to be inhibited by high ammonium concentrations in wastewater treatment (Anthonisen et al. 1976), but also in river sediments, where ammonium has been demonstrated to specifically affect Nitrosomonas sp. (Smith et al. 1997). Thus, the different water-soluble ammonium levels in the different soils at identical sludge dosages can be at least in part related to variation in microbial communities, with contrasted decomposition and ammonium release rates, but also with clearly different sensitivities to nitrification inhibition. In addition soil properties might themselves influence the levels of these soluble compounds, through the effects on bioavailability, but also due to direct effects on microbial communities. As an example, coarse textures might increase the aeration and decrease ammonium levels in soil due to facilitated ammonium volatilization (Kirchmann and Witter 1989) but also through an enhanced nitrification (Buss et al. 2004), while increased CEC might decrease the ammonium levels in soil (Roy and Krapac 2006). 


\subsection{Effects on collembolan survival}

The importance of pore-water pollutant concentrations for collembolans in the specific case of sludges has already been reported in previous studies that have shown that acute and chronic toxicity of different sludges for soil and aquatic organisms was mainly mediated by water soluble compounds, among which ammonium might play a central role (Domene et al. 2008, Ramírez et al. 2008). In our study, the principal role of soluble ammonium has been shown, since collembolan mortality appeared to be mainly and positively explained by water-soluble ammonium and phosphate concentrations, and negatively related to organic carbon content (Table 5). The inclusion of phosphate in the model led to the best fit, despite the fact that this parameter was not itself significant. The model was reasonably acceptable, since it explained $72 \%$ of the variability in mortality. The link between ammonium/ammonia and toxicity and has been reported in other works, studying their impact on aquatic invertebrates (Fjällborg and Dave 2003, Hickey and Vickers 2004, Domene et al. 2008)), soil invertebrates (Neher and Barbercheck 1998, Domene et al. 2007a, Domene et al. 2008) and plants (Britto and Kronzucker 2002, Ramírez et al. 2008).

Ammonium is released with sludge microbial decomposition, as shown by the significantly higher ammonium levels in the water soil phase after soil amendments with sewage sludge during the first weeks, where higher decomposition rates occur. Later, such releases cease and other nitrogen forms, nitrate and nitrite, become dominant (Qiang et al. 2004, Van Niekerk et al. 2006). However, the pore water ammonium levels released from the same sludge might vary considerably in different soils. First, the amount of ammonium released with sludge decomposition can change substantially depending on the environmental conditions (Miller 1974), but also depending on the microorganism communities present and their activities after the amendment (Anthonisen et al. 1976, Stark et al. 2008). Second, ammonium can be strongly retained in the soil solid phase by the cation exchange sites of clay, metal oxides, and organic matter (Huber et al. 1977, Buss et al. 2004, Roy and Krapac 2006). Third, ammonium levels in the soil pore water are not static, and this compound is oxidized to nitrate 
by nitrifying bacteria, in a process mainly carried out in aerobic conditions (Buss et al. 2004). Finally, ammonium can be transformed to ammonia under neutral and alkaline conditions, which are generally associated with decomposition in aerobic environments, and given the high volatility of ammonia, can be released from soil (Kirchmann and Witter 1989). Hence, although ammonia can accumulate in soil pore water coming from the decomposition of organic wastes, the combined action of sorption, biotransformation, and volatilization can reduce its bioavailable concentration in pore-water and thus the observed toxicity.

Concerning the influence of soil properties on the sludge, our results suggest that ammonium sorption to organic matter might be at least one of the main reasons for the decreased toxicities in soils with higher organic matter content. However, this might be also be linked to the higher CEC of these soils, since in the set of soils used, CEC was correlated with organic carbon ( $\mathrm{r}=$ 0.688, $\mathrm{p}=0.04$ ) but not with clay content. The lower toxicity of chemicals in soils with higher CEC is related to its influence on bioavailability (Lock and Janssen 2001a, Lock and Janssen 2001b, Simini et al. 2004). As an example, several authors have demonstrated CEC to be the best indicator to predict the bioavailability of metals to soil invertebrates (Lock et al. 2000, Lock and Janssen 2001a, Römbke et al. 2006) and plants (Rooney et al. 2006), as a result of the joint contribution of clay and organic matter, as well as other adsorption phases such as oxyhydroxides. Similarly, the toxicity of pollutants is generally lower the higher the organic matter content, as shown for enchytraeids, earthworms, collembolans and plants (Martikainen 1996, Spurgeon and Hopkin 1996, Martikainen and Krogh 1999, Simini et al. 2004, Amorim et al. 2005b, Dayton et al. 2006). However, in our study CEC was not included in the model explaining the effect on survival, while organic carbon was.

Alternatively, the association between higher organic carbon levels and lower toxicity might be related to a higher availability of unpolluted food sources in the more organic soils that might decrease the consumption of sludge and hence the soil toxicity. The reduced feeding on sludge when a clean food source is available has been reported for Folsomia fimetaria and F. candida (Krogh et al. 1997, Domene 2007a, respectively). However, the clear correlation between 
soluble ammonium and toxicity rather supports the first hypothesis of ammonium sorption to organic matter.

Regarding the contribution of phosphate to toxicity, this is disagreement with lack of noxious effects of this compound described to date for soil organisms. As an example, no effects of phosphorus fertilization have been shown for nematode diversity in pastures (Sarathchandra et al. 2001) neither for grassland collembolan populations, where even stimulatory effects were observed (King and Hutchinson 1980). Phosphate contribution to the survival model in this study might be an artifact rather than a true toxic effect, since phosphate was positively correlated with ammonium levels, in accordance with that observed for most of the ions measured (Table 4).

\subsection{Effects on collembolan reproduction}

Regarding the model derived for reproduction, it included a negative influence of soluble ammonium, nitrite, phosphate, $\mathrm{pH}_{\text {soil, }}$ and $\mathrm{C} / \mathrm{N}$ ratio, and a positive influence of organic carbon content (Table 6). Again, the model was reasonably acceptable because all the parameters included were significant and the model explained $72 \%$ of the variability in reproduction inhibition. The wider variety of parameters included in the model, compared to the survival model, is in accordance with this being considered as a more sensitive integrative endpoint. However, it is noteworthy that the model obtained for reproduction was consistent with that obtained for survival. More precisely, the negative contribution of soluble ammonium levels appeared again linked to the toxicity observed, while the positive contribution of organic matter suggests sorption of ammonium, which decreases its bioavailability and toxicity. Again, phosphate influenced this endpoint negatively, and due to the lack of toxicity of this compound, its contribution might be more an artifact than a true effect due to its correlation with ammonium levels.

Furthermore nitrite levels were also found to explain the toxicity for reproduction, in accordance with other studies that have demonstrated the toxicity of this compound for microorganisms, 
plants and soil organisms (Phipps and Cornforth 1970, Hamilton and Lowe 1981). This seems to be a real effect because nitrite levels were uncorrelated with ammonium levels (Table 4).

Regarding other soil properties influencing our results, the $\mathrm{pH}$ of the soil-sludge mixtures was found to contribute negatively to the effects on reproduction. This result is difficult to explain since toxicity was expected to decrease with alkaline $\mathrm{pH}$, when ammonia losses by volatilization and the presence of nitrifiers are generally more likely (Ferguson et al. 1984, Hankinson and Schmidt 1998). In addition, $\mathrm{pH}$ was uncorrelated with the remaining soil properties measured. A possible explanation for this pattern might be the high sensitivity of this species' reproduction to alkaline soils, where reproduction nearly ceases (Greenslade and Vaughan 2003, Jänsch et al. 2005). This might have resulted in an enhanced toxicity of sludge due to the unsuitability of high $\mathrm{pH}$ soils.

On the other hand, we found that higher $\mathrm{C} / \mathrm{N}$ values increased the toxicity of sludge for reproduction. We also observed that generally soils with higher $\mathrm{C} / \mathrm{N}$ ratios showed low nitrification values, suggesting that their increased toxicity might be related to a reduced loss of ammonia by nitrification. The negative correlation between $\mathrm{C} / \mathrm{N}$ ratio and nitrification has been shown in different ecosystems (Ste-Marie and Paré 1999, Ollinger et al. 2002), but the mechanism underlying this pattern is still not clear. As an example, it has been reported that in grassland and forest carbon-rich soils the absence or reduced presence of nitrifying bacteria compared to other soils could explain the low nitrate levels, where mineral nitrogen is mainly found as ammonium (Verhagen et al. 1992, Blew and Parkinson 1993, Hart et al. 1994, SteMarie and Paré 1999). It has been also proposed that the nitrogen limitation in soils with high $\mathrm{C} / \mathrm{N}$ ratios and the consequent lower decomposition, results in competition for the ammonium between nitrifying and heterotrophic bacteria, thus reducing nitrate production (Verhagen et al. 1992). Although we lack microbiological data, the first rather than the second explanation is more likely to be applicable to our set of soils, since ammonium production was apparent in all the soils tested. 


\section{CONCLUSIONS}

The results of our study showed a principal role of ammonium in the toxicity of soil amendments with sludge for collembolans, especially regarding mortality. In addition, we also demonstrated the reduced toxicity in soils with higher organic matter levels, which can decrease ammonium bioavailability through its higher cation sorption capacity. Concerning the effects on reproduction, soluble nitrite was also identified as a contributor to the toxicity observed, while higher $\mathrm{C} / \mathrm{N}$ ratio and soil $\mathrm{pH}$ were shown to increase the toxicity, due to limited nitrification in these soils and the unsuitability of alkaline soils for the reproduction of this species, respectively.

\section{AKNOWLEDGEMENTS}

This study was funded by the LODOTOX project of the Spanish Ministry of Science and Technology (AGL2002-03297). We also thank the contribution of the MONTES project of the Spanish Ministry of Science and Innovation (CONSOLIDER INGENIO 2010, CSD208800040) and the 'Master and Back' fellowship of the Regione Autonoma della Sardegna granted to M.V. Uras.

\section{REFERENCES}

Amorim, M.J.B, Römbke, J., Schallnaß, H.-J., Soares, A.M.V.M., 2005a. Effect of soil properties and aging on the toxicity of copper for Enchytraeus albidus, Enchytraeus luxuriousus, and Folsomia candida. Environmental Toxicology and Chemistry 24, 1875-1885. Amorim, M.J.B, Römbke J., Scheffczyk A., Soares, A.M.V.M., 2005b. Effect of different soil types on the enchytraeids Enchytraeus albidus and Enchytraeus luxuriosus using the herbicide Phenmedipham. Chemosphere 61, 1102-1114. 
Anderson, P.R., Christensen, T.H., 1988. Distribution coefficients of Cd, Co, Ni and Zn in soils. Journal of Soil Science 39, 15-22.

Anthonisen, A.C., Loehr, R.C., Prakasam, T.B.S, Srinath, E.G., 1976. Inhibition of nitrification by ammonia and nitrous acid. Journal Water Pollution Control Federation 48, 835-852.

Bauer, C., Römbke, J., 1997. Factors influencing the toxicity of two pesticides on three lumbricid species in laboratory tests. Soil Biology and Biochemistry 29, 70-708.

Blew, R.D., Parkinson, D., 1993. Nitrification and denitrification in a white spruce forest in southwest Alberta, Canada. Canadian. Journal of Forest Research 23, 1715-1719.

Bollag, J.-M, Henninger, N.M., 1978. Effects of nitrite toxicity on soil bacteria under aerobic and anaerobic conditions. Soil Biology and Biochemistry 10, 377-381.

Bongers, M., Rusch, B., Van Gestel, C.A.M., 2004. The effect of counterion and percolation on the toxicity of lead for the springtail Folsomia candida in soil. Environmental Toxicology and Chemistry 23, 195-199.

Boyd, W.A., Williams, P.L., 2003. Availability of metals to the nematode Caenorhabditis elegans: toxicity based on total concentrations in soil and extracted fractions. Environmental Toxicology and Chemistry 22, 1100-1106.

Bradham, K.D., Dayton, E.A., Basta, N.T., Schroder, J., Payton, M., Lanno, R., 2006. Effect of soil properties on lead bioavailability and toxicity to earthworms. Environmental Toxicology and Chemistry 25, 769-775.

Britto, D.T., Kronzucker, H.J., 2002. $\mathrm{NH}_{4}{ }^{+}$toxicity in higher plants: a critical review. Journal of Plant Physiology 159, 567-584.

Büchi Labortechnik., 2002. Total nitrogen determination according to Kjeldahl with the BÜCHI Kjeldahl line. Application note No. 3XX001.en, version A.

Buss, S.R., Herbert, A.W., Morgan, P., Thornton, S.F., Smith, J.W.N. 2004. A review of ammonium attenuation in soil and groundwater. Quarterly Journal of Engineering Geology and Hydrogeology 37, 347-359. 
Crommentuijn, T., Brils, J., van Straalen, N.M., 1993. Influence of cadmium on life-history characteristics of Folsomia candida (Willem) in an artificial soil substrate. Ecotoxicology and Environmental Safety 26, 216-227.

Crouau, Y., Tam Tchiam, S., 2006. Importance of the nature of the dilution soils for the evaluation of toxicity of a polluted soil by a collembolan assay. Applied Soil Ecology 34, 280283.

Dayton, E.A., Basta, N.T., Payton, M.E., Bradham, K.D., Schroder, J.L., Lanno, R.P., 2006. Evaluating the contribution of soil properties to modifying lead phytoavailability and phytotoxicity. Environmental Toxicology and Chemistry 25, 719-725.

Domene, X., Alcañiz, J.M., Andrés, P., 2008. Comparison of solid-phase and eluate assays to gauge the ecotoxicological risk of organic wastes on soil organisms. Environmental Pollution 151, 549-558.

Domene, X., Natal-da-Luz, T., Alcañiz, J.M., Andrés, P., Sousa, J.P., 2007b. Fedding inhibition in the soil collembolan Folsomia candida as an endpoint for the estimation of organic waste ecotoxicity. Environmental Toxicology and Chemistry 26, 1538-154.

Domene, X., Alcañiz, J.M., Andrés, P., 2007a. Ecotoxicological assessment of organic wastes using the soil collembolan Folsomia candida. Applied Soil Ecology 35, 461-472.

Domenico, P.A., Schwartz, F.W., 1998. Physical and Chemical Hydrogeology. Wiley, New York, USA.

Dontsova, K.M., Norton, L.D., Johnston, C.T., 2005. Calcium and magnesium effects on ammonia adsorption by soil clays. Soil Science Society of America Journal 69, 1225-1232.

Echevarria, G., Massoura, S.T., Sterckeman, T., Becquer, T., Schwartz, C., Morel, J.L., 2006. Assessment and control of the bioavailability of nickel in soils. Environmental Toxicology and Chemistry 25, 643-651.

EN 12879., 2000. Characterization of sludges. Determination of the loss of ignition of dry mass. European Committee for Standardization, Brussels, Belgium. 
EN 12880., 2000. Characterization of sludges. Determination of dry residue and water content. European Committee for Standardization, Brussels, Belgium.

EN 13037., 1999. Soil improvers and growing media - Determination of pH. European Committee for Standardization, Brussels, Belgium.

EN 13038., 1999. Soil improvers and growing media - Determination of electrical conductivity. European Committee for Standardization, Brussels, Belgium.

EN 13342., 2000. Characterization of sludges. Determination of Kjeldahl nitrogen. European Committee for Standardization, Brussels, Belgium.

European Communities., 2000. Working Document on Sludge: 3rd Draft. ENV.E.3/LM. Brussels, Belgium.

Ferguson, R.B., Kissel, D.E., Koelliker, J.K., Basel, W., 1984. Ammonia volatilization from surface-applied urea: effect of hydrogen ion buffering capacity. Soil Sci Soc Am J 48, 578-582. Fjällborg, B., Dave, G., 2003. Toxicity of copper in sewage sludge. Environment International 28, 761-769

Fountain, M.T., Hopkin, S., 2005. Folsomia candida (Collembola): A “standard” soil arthropod. Annual Review of Entomology 50, 201-222.

Fountain, M.T., Hopkin S.P. 2004a., Continuous monitoring of Folsomia candida (Insecta: Collembola) in a metal exposure test. Ecotoxicology and Environmental Safety 48, 275-286.

Fountain, M.T., Hopkin, S.P., 2004b. A comparative study of the effects of metal contamination on collembolan in the field and in the laboratory. Ecotoxicology 13, 573-587.

Fountain, M.T., Hopkin, S., 2005. Folsomia candida (Collembola): A “standard” soil arthropod. Annual Review of Entomology 50, 201-222.

Gejlsbjerg, B., Klinge, C., Samsøe-Petersen, L., Madsen, T. 2001. Toxicity of linear alkylbenzene sulfonates and nonylphenol in sludge-amended soil. Environmental Toxicology and Chemistry 20, 2709-2713.

Greenslade, P., Vaughan, G.T., 2003. A comparison of Collembola species for toxicity testing of Australian soils. Pedobiologia 47, 171-179. 
Greenslade, P., Vaughan, G.T., 2003. A comparison of Collembola species for toxicity testing of Australian soils. Pedobiologia 47,171-179

Hamilton, J.L., Lowe, R.H., 1981. Organic matter and N effects on soil nitrite accumulation and resultant nitrite toxicity to tobacco transplants. Agron J 73, 787-790.

Hankinson, T.R., Schmidt, E.L., 1998. An acidophilic and a neutrophilic Nitrobacter strain isolated from the numerically predominant nitrite-oxidizing population of an acid forest soil. Applied and Environmental Microbiology 54, 1536-1540.

Hart, S.C., Nason, G.E., Myrold, D.D., Perry, DA., 1994. Dynamics of gross nitrogen transformations in an old-growth forest: the carbon connection. Ecology 75, 880-891.

Hickey, C.W., Vickers M.L., 1994. Toxicity of ammonia to nine native New Zealand freshwater invertebrate species. Archives of Environmental Contamination and Pollution 26, 292-298.

Hickey C.W., Vickers M.L., 2004., Toxicity of ammonia to nine native New Zealand freshwater invertebrate species. Archives of Environmental Contamination and Toxicology 26, 292-298.

Hofman, J., Hovorková, I., Machát, J., 2009. Comparison and characterization of OECD artificial soil, in: Moser, H., Römbke, J. (Eds.), Ecotoxicological characterization of waste. Springer. New York, pp. 223-243.

Huber, D.M., Warren, H.L., Nelson, D.W., Tsai, CY., 1977. Nitrification inhibitors - New tools for food production. BioScience 27, 523-529.

ISO 10390., 2005. Soil quality - Determination of $\mathrm{pH}$. International Organization for Standardization, Geneva, Switzerland.

0ISO 11267., 1999. Soil quality - Inhibition of reproduction of Collembola (Folsomia candida) by soil pollutants. International Organization for Standardization, Geneva, Switzerland.

ISO 11885., 1996. Water quality - Determination of 33 elements by inductively coupled plasma atomic emission spectroscopy. International Organization for Standardization, Geneva, Switzerland. 
ISO 17512-1., 2005. Soil quality - Avoidance test for testing the quality of soils and effects of chemicals on behaviour - Part 1: Test with earthworms (Eisenia fetida and Eisenia andrei). International Organization for Standardization, Geneva, Switzerland.

ISSS-ISRIC-FAO., 1998. World Reference Base for Soil Resources. World Soil Resources Reports 84. Food and Agriculture Organization of the United Nations, Rome, Italy.

Jänsch, S., Amorim, M.J., Römbke, J., 2005. Identification of the ecological requirements of important terrestrial ecotoxicological test species. Environ Rev 13, 51-83.

Katayama, A., Hirai, M., Shoda, M., Kubota, H. 1985. Inhibitory factor of sewage sludge compost for growth of Komatsuna Brassica campestris L. var. rapifera. Environmental Pollution (Series A) 38, 45-62.

King, K.L., Hutchinson, K.J., 1980. Effects of superphosphate and stocking intensity on grassland microarthropods. Journal of Applied Ecology 17, 581-591.

Kirchmann, H., Witter, E., 1989. Ammonia volatilization during aerobic and anaerobic manure decomposition. Plant and Soil 115, 35-41.

Krogh, P.H., Holmstrup, M., Jensen, J., Petersen, S.O., 1997. Ecotoxicological assessment of sewage sludge in agricultural soil.Working Report 69. Ministry of Environment and Energy.

Danish Environmental Protection Agency, Copenhagen.

Lock, K., Janssen, C.R., 2001a. Ecotoxicology of mercury to Eisenia fetida, Enchytraeus albidus, and Folsomia candida. Biology and Fertility of Soils 34, 219-221.

Lock, K., Janssen, C.R., 2001b. Modeling zinc toxicity for terrestrial invertebrates. Environmental Toxicology and Chemistry 20, 1901-1908.

Lock, K., Janssen, C.R., 2002a. Ecotoxicology of chromium (III) to Eisenia fetida, Enchytraeus albidus, and Folsomia candida. Ecotoxicology and Environmental Safety 51, 203-205.

Lock, K., Janssen, C.R., 2002b. Ecotoxicology of nickel to Eisenia fetida, Enchytraeus albidus, and Folsomia candida. Chemosphere 46, 197-200.

Lock, K., Janssen, C.R., 2001a. Effect of clay and organic matter type on the ecotoxicity of zinc and cadmium to the potworm enchytraeus albidus. Chemosphere 44, 1669-1672. 
Lock, K., Janssen, C.R., 2001b. Modeling zinc toxicity for terrestrial invertebrates. Environmental Toxicology and Chemistry 20, 1901-1908.

Lock, K., Janssen, C.R., 2001c. Cadmium toxicity for terrestrial invertebrates: taking into account soil parameters affecting bioavailability into account. Ecotoxicology 10, 315-322.

Lock, K., Janssen, C.R., 2003. Influence of aging on copper bioavailability in soils. Environmental Toxicology and Chemistry 22, 1162-1166.

Lock, K., Janssen, C.R., De Coen, W.M., 2000. Multivariate test designs to assess the influence of zinc and cadmium bioavailability in soils on the toxicity to Enchytraeus albidus. Environmental Toxicology and Chemistry 19, 2666-2671.

MAFF., 1993. Review of the rules for sewage sludge application to agricultural land. Food safety and relevant animal health aspects of potentially toxic elements. MAFF Publications, London, UK.

Martikainen, E., 1996. Toxicity of dimethoate to some animal species in different soil types. Ecotoxicology and Environmental Safety 33, 128-136.

Martikainen, E.A.T., Krogh, P.H., 1999. Effects of soil organic matter content and temperature on toxicity of dimethoate to Folsomia fimetaria (Collembola:Isotomidae). Environmental Toxicology and Chemistry 18, 865-872.

McBride, M.B., 2003. Toxic metals in sewage sludge-amended soils: has promotion of beneficial use discounted the risks? Advances in Environmental Research 8, 5-19.

McBride, M.B., Richards, B.K., Steenhuis, T., 2004. Bioavailability and crop uptake of trace elements in soil columns amended with sewage sludge products. Plant and Soil 262, 71-84.

Miller, R.H., 1974. Factors affecting the decomposition of an anaerobically digested sewage sludge in soil. J Environ Qual 3, 376-38.

Neher, D.A., Barbercheck, M.E., 1998. Diversity and function of soil mesofauna, in: Collins, W.W., Qualset, C.O. (Eds.), Biodiversity in Agroecosystems. CRC Press, Boca Raton, pp. 2747. 
Neher, D.A., 1999. Soil community and ecosystem processes. Agroforestry Systems 45, 159185.

OECD, 207, 1984. Earthworm, acute toxicity tests. OECD Guideline for testing of Chemicals. Organization for Economic Co-operation and Development, Paris, France.

Ollinger, S.V., Smith, M.L., Martin, M.E., Hallet, R.A., Goodale, C.L., Aber, J.D., 2002. Regional variation in foliar chemistry and $\mathrm{N}$ cycling among forests of diverse history and composition. Ecology 83, 339-355

Pascual, J.A., Ayuso, M., Garcia, C., Hernández, T., 1997. Characterization of urban wastes according to fertility and phytotoxicity parameters. Waste Management and Research 15, 103112.

Pedersen, M.B., van Gestel, C.A.M,. 2001. Toxicity of copper to the collembolan Folsomia fimetaria in relation to the age of soil contamination. Ecotoxicology and Environmental Safety 49, 54-59.

Peijnenburg, W.J.G.M., Posthuma, L., Zweers, P.G.P.C., Baerselman, R., de Groot, A.C., van Veen, R.P.M., Jager, T., 1999. Prediction of metal bioavailability in Dutch field soils for the Oligochaete Enchytraeus crypticus. Ecotoxicology and Environmental Safety 43, 170-186.

Phipps, R.H., Cornforth, I.S., 1970. Factors affecting the toxicity of nitrite nitrogen to tomatoes. Plant and Soil 33, 1573-5036.

Qiang, Z., Speir, T.W., van Schaik, A.P., 2004. Leaching of nutrients from soil cores treated with single large dose of digested sewage sludge. Biology and Fertility of Soils 40, 284-289.

Ramírez, W.A., Domene, X., Andrés, P., Alcañiz, J.M., 2008. Phytotoxic effects of sewage sludge extracts on the germination of three plant species. Ecotoxicology 17, 834-844.

Richardson, J., 1997. Acute ammonia toxicity for eight New Zealand indigenous freshwater species. New Zealand Journal of Marine and Freshwater Research 31, 185-190.

Römbke, J., Jänsch, S., Junker, T., Pohl, B., Scheffczyk, A., Schallnaß, H.-J. 2006. Improvement of the applicability of ecotoxicological tests with earthworms, springtails and 
plants for the assessment of metals in natural soils. Environmental Toxicology and Chemistry 25, 776-787.

Rooney, C.P., Zhao, F.-J., McGrath, S.P., 2006. Soil factors controlling the expression of copper toxicity to plants in a wide range of European soils. Environmental Toxicology and Chemistry 25, 726-732.

Rovira, P., Vallejo, V.R., 2002. Labile and recalcitrant pools of carbon and nitrogen in organic matter decomposing at different depths in soil: an acid hydrolysis approach. Geoderma 107, $109-141$.

Roy, W.R., Krapac, I.G., 2006. Potential soil cleanup objectives for nitrogen-containing fertilizers at agrichemical facilities. Soil and Sediment Contamination 15, 241-251.

Sandifer, R.D., Hopkin, S.P., 1996. Effects of pH on the toxicity of cadmium, copper, lead and zinc to Folsomia candida Willem, 1902 (Collembola) in a standard laboratory test system. Chemosphere 33, 2475-2486.

Sarathchandra, S.U., Ghani, A., Yeates, G.W., Burch, G., Cox, N.R., 2001. Effect of nitrogen and phosphate fertilisers on microbial and nematode diversity in pasture soils. Soil Biology and Biochemistry 33, 953-964.

Seniczak, S., Klimek, A., Kaczmarek, S., 1994., The mites (Acari) of an old Scots pine forest polluted by a nitrogen fertilizer factory at Wloclawek (Poland). II: litter/soil fauna. Zoologische Beiträge NF 35, 199-216.

Simini, M., Checkai, R.T., Kuperman, R.G., Phillips, C.T., Kolakowski, J.E., Kurnas, C.W., 2004. Assessing TNT toxicity on soils with contrasting characteristics using soil invertebrate toxicity tests. Report A741334. Edgewood Chemical Biological Center, Aberdeen, United States.

Smit, C.E, van Gestel, C.A.M., 1998. Effects of soil type, prepercolation, and ageing on bioaccumulation and toxicity of zinc for the springtail Folsomia candida. Environmental Toxicology and Chemistry 17, 1132-1141. 
Smith, M.S., Tiedje, J.M., 1979. Phases of denitrification following oxygen depletion in soil. Soil Biol Biochem 11, 261-267.

Smith, R.V., Burns, L.C., Doyle, R.M., Lennox, R.D., Kelso, B.H.L, Foy, R.H., Stevens, R.J., 1997. Free ammonia inhibition of nitrification in river sediments leading to nitrite accumulation. J Environ Qual 26, 1049-1055.

Spurgeon, D.J., Hopkin, S.P., 1996. Effects of variations of the organic matter content and pH of soils on the availability and toxicity of zinc to the earthworm Eisenia fetida. Pedobiologia 40, 80-96.

Stark, C.H., Condron, L.M., O’Callaghan, M., Stewart, A., Di, H.J., 2008. Differences in soil enzyme activities, microbial community structure and short-term nitrogen mineralisation resulting from farm management history and organic matter amendments. Soil Biology and Biochemistry 40, 1352-1363.

Ste-Marie, C., Paré, D., 1999. Soil, pH, and N availability effects on net nitrification in the forest floors of a range of boreal forest stands. Soil Biology and Biochemistry 31, 1579-1589.

Stephenson, G.L., Koper, N., Atkinson, G.F., Salomon, K.R., Scroggins, R.P., 2000. Use of nonlinear regression techniques for describing concentration response relationships of plant species exposed to contaminated site soils. Environ Toxicol Chem 19, 2968-2981.

Sverdrup, L.E., Kelley, A.E., Krogh, P.H., Nielsen, T., Jensen, J., Scott-Fordsmand, J.J., Stenersen, J., 2001. Effects of eight polycyclic aromatic compounds on the survival and reproduction of the springtail Folsomia fimetaria L. (Collembola, Isotomidae). Environmental Toxicology and Chemistry 20, 1332-1338.

Sverjensky, D.A., Sahai, N., 1996. Theoretical prediction of single-site surface-protonation equilibrium constants of oxides and silicates in water. Geochimica et Cosmochimica Acta 60, 3773-3797.

Van Gestel, C.A.M., 1997. Scientific basis for extrapolating results from soil ecotoxicity tests to field conditions and the use of bioassays, in: Van Straalen, N.M., Løkke H. (Eds.), Ecological Risk Assessment of Contaminants in Soils. Chapman and Hall, London, UK. 
Van Gestel, C.A.M., Koolhaas, J.E., 2004. Water-extractability, free ion activity, and pH explain cadmium sorption and toxicity to Folsomia candida (Collembola) in seven soil-pH combinations. Environmental Toxicology and Chemistry 23, 1822-1833.

Van Gestel, C.A.M., Rademaker, M.C.J., van Straalen, N.M., 1995. Capacity controlling parameters and their impact on metal toxicity, in: Salomons, W., Stigliani, W.M. (Eds.), Biogeodynamics of pollutants in Soils and Sediments. Springer-Verlag, New York, United States.

Van Gestel, C.A.M., Van Dis, W.A., 1988. The influence of soil characteristics on the toxicity of four chemicals to the earthworm Eisenia andrei (Oligochaeta). Biology and Fertility of Soils 6, 262-265.

Van Niekerk, C., Claassens, A., Snyman, H., 2005. N transformation in incubated sewage sludge and commercial fertilizer enriched soil. Communications in Soil Science and Plant Analysis 36, 743-757.

Verhagen, F.J.M., Duyts, H., Laanbroek, H.J., 1992. Competition for ammonium between nitrifying and heterotrophic bacteria in continuously percolated soil columns. Applied and Environmental Microbiology 58, 3303-3311.

Vijver, M., Jager, T., Posthuma, L., Peijnenburg, W., 2001. Impact of metal pools and soil properties on metal accumulation in Folsomia candida (Collembola). Environmental Toxicology and Chemistry 20, 712-720.

\section{FIGURE CAPTIONS}

Figure 1. pH and electrical conductivity of soil-sludge mixtures, at the end of the experiment, in the different soils and sludge dosages tested; $n=1$.

Figure 2. Soil-sludge mixtures water-soluble ions, at the end of the experiment, in the different soils and sludge dosages tested. Bars represent standard deviation; $\mathrm{n}=3$. 
Table 1. Characterization of the soils collected from different sites in Catalonia (NE Spain). All values are expressed on dry basis, with the exception of WHC, expressed as on fresh weight basis. Soil classification is in accordance with (ISS-ISRIC-FAO 1998); WHC = maximum water holding capacity; CEC = cation exchange capacity.

\begin{tabular}{|c|c|c|c|c|c|c|c|c|c|c|}
\hline Soil & OECD & CAM & COLL & GAN & GRA & POR & PRA2 & RIU & STA & VALL \\
\hline Site & Artificial & Campdàsens & Collsacreu & Gandesa & La Granadella & Porrera & Prades & Riudellots & Santa Fe & Vallgorguina \\
\hline & & Leptic & Dystric & Haplic & Hypercalcic & Leptic & Eutric & Vertic & Dystric & Haplic \\
\hline Soil classification & - & Calcisol & Regosol & Calcisol & Calcisol & Regosol & Arenosol & Luvisol & Cambisol & Arenosol \\
\hline Soil use & - & Shrubland & Forest & Vineyard & Olive grove & Vineyard & Grassland & Grainfield & Forest & Forest \\
\hline WHC (\%) & 44.8 & 44.9 & 33.9 & 37.6 & 49.8 & 38.8 & 28.1 & 45.0 & 50.7 & 29.9 \\
\hline pH (soil:water 1:5) & 6.2 & 7.9 & 4.9 & 8.3 & 8.2 & 6.9 & 6.5 & 7.3 & 5.7 & 6.4 \\
\hline Sand (\%) & 51.9 & 32.0 & 72.7 & 76.0 & 27.8 & 67.6 & 80.3 & 58.6 & 80.2 & 84.5 \\
\hline Silt (\%) & 31.8 & 37.9 & 17.6 & 12.0 & 48.5 & 20.4 & 16.5 & 13.8 & 8.7 & 8.3 \\
\hline Clay (\%) & 16.3 & 30.1 & 9.7 & 12.0 & 23.69 & 11.9 & 3.2 & 27.6 & 11.1 & 7.2 \\
\hline Organic matter (\%) & 6.9 & 8.4 & 3.8 & 0.6 & 1.70 & 4.3 & 1.9 & 1.9 & 12.0 & 2.2 \\
\hline Organic carbon (\%) & 4.0 & 4.8 & 2.2 & 0.3 & 0.99 & 2.5 & 1.1 & 1.1 & 6.9 & 1.3 \\
\hline Total N (\%) & 0.04 & 0.3 & 0.11 & 0.04 & 0.11 & 0.20 & 0.10 & 0.13 & 0.53 & 0.08 \\
\hline $\mathrm{C} / \mathrm{N}$ & 100 & 16.2 & 19.9 & 8.7 & 9.0 & 11.3 & 11.2 & 8.5 & 13.1 & 15.7 \\
\hline CEC $\left(\mathrm{cmol} \mathrm{kg}^{-1}\right)$ & 8.94 & 22.3 & 9.2 & 6.0 & 14.2 & 18.6 & 7.3 & 14.9 & 17.7 & 9.2 \\
\hline $\mathbf{C d}\left(\mathrm{mg} \mathrm{kg}^{-1}\right)$ & - & 0.2 & $<0.1$ & $<0.1$ & 0.2 & 0.2 & 0.9 & $<0.1$ & $<0.1$ & $<0.1$ \\
\hline $\mathbf{C u}\left(\mathrm{mg} \mathrm{kg}^{-1}\right)$ & - & 23.0 & 8.0 & 20.0 & 26.0 & 92.0 & 77.0 & 26.0 & 11.0 & 16.0 \\
\hline $\mathrm{Cr}\left(\mathrm{mg} \mathrm{kg}{ }^{-1}\right)$ & - & 39.0 & 10.0 & 16.0 & 19.0 & 67.0 & 11.0 & 22.0 & 13.0 & 9.0 \\
\hline $\mathbf{N i}\left(\mathrm{mg} \mathrm{kg}^{-1}\right)$ & - & 19.0 & $<10$ & 32.0 & 28.0 & 46.0 & $<10$ & 18.0 & $<10$ & $<10$ \\
\hline $\mathbf{P b}\left(\mathrm{mg} \mathrm{kg}^{-1}\right)$ & - & 23.0 & 17.0 & 11.0 & 10.0 & 147.0 & 48.0 & 19.0 & 41.0 & 14.0 \\
\hline $\mathbf{Z n}\left(\mathrm{mg} \mathrm{kg}^{-1}\right)$ & - & 94.0 & 62.0 & 32.0 & 42.0 & 420.0 & 204.0 & 64.0 & 145.0 & 85.0 \\
\hline
\end{tabular}


Table 2. Physico-chemical properties, heavy metal and organic pollutant contents of the thermally dried sewage sludge; ${ }^{a}$ Over the limit value of the current legislation on sludge in Europe (Directive 86/278/EEC); ${ }^{b}$ Over the limit value in the 3rd draft of Working Document on sludge (European Communities, 2000). All the values expressed as dry weight basis, with the exception of dry matter and water holding capacity (WHC). DEHP= $\operatorname{di}(2-$ ethylhexyl)phthalates; $L A S=$ linear alkylbenzene sulphonates; $N P E=$ nonylphenols; $P A H=$ polycyclic aromatic hydrocarbons; $P C B=$ polychlorinated biphenyls; $P C D D / F=$ Polychlorinated dibenzodioxins and dibenzofuranes.

\begin{tabular}{ccc}
\hline Parameter & Units & Value \\
\hline Dry matter & $\%$ & 94.5 \\
WHC & $\%$ & 74.7 \\
pH & water, 1:5 (v/v) & 6.9 \\
Electrical & & \\
conductivity & $\mathrm{dS} \mathrm{m}{ }^{-1}, 25^{\circ} \mathrm{C}$ & 3.57 \\
Organic matter & $\mathrm{g} \mathrm{kg}^{-1}$ & 687 \\
Stable organic & & \\
matter & $\%$ & 40.4 \\
$\mathrm{~N}$ & $\mathrm{~g} \mathrm{~kg}^{-1}$ & 60.6 \\
Non-hydrolyzable & & \\
$\mathrm{N}$ & $\mathrm{g} \mathrm{kg}^{-1}$ & 19.1 \\
Hydrolyzable N & $\mathrm{g} \mathrm{kg}^{-1}$ & 41.5 \\
$\mathrm{NH}$-N & $\mathrm{g} \mathrm{kg}^{-1}$ & 8.0 \\
$\mathrm{P}$ & $\mathrm{g} \mathrm{kg}^{-1}$ & 20.5 \\
$\mathrm{~K}$ & $\mathrm{~g} \mathrm{~kg}^{-1}$ & 2.2 \\
$\mathrm{Cd}$ & $\mathrm{mg} \mathrm{kg}^{-1}$ & 1.3 \\
$\mathrm{Cr}$ & $\mathrm{mg} \mathrm{kg}^{-1}$ & 30 \\
$\mathrm{Cu}$ & $\mathrm{mg} \mathrm{kg}^{-1}$ & 645 \\
$\mathrm{Hg}$ & $\mathrm{mg} \mathrm{kg}^{-1}$ & 0.95 \\
$\mathrm{Ni}$ & $\mathrm{mg} \mathrm{kg}^{-1}$ & 53 \\
$\mathrm{~Pb}$ & $\mathrm{mg} \mathrm{kg}^{-1}$ & $3747^{\mathrm{a}}$ \\
$\mathrm{Zn}$ & $\mathrm{mg} \mathrm{kg}^{-1}$ & 952 \\
$\mathrm{DEHP}$ & $\mathrm{mg} \mathrm{kg}^{-1}$ & 27 \\
LAS & $\mathrm{mg} \mathrm{kg}^{-1}$ & 331 \\
$\mathrm{NPEO}$ & $\mathrm{mg} \mathrm{kg}^{-1}$ & $76^{\mathrm{b}}$ \\
$\mathrm{PAH}$ & $\mathrm{mg} \mathrm{kg}^{-1}$ & 0.3 \\
PCB & $\mathrm{mg} \mathrm{kg}^{-1}$ & 0.029 \\
PCDD/F & $\mathrm{ng} \mathrm{TEQ} \mathrm{kg}$ & 13.7 \\
\hline & &
\end{tabular}


Table 3. F. candida toxicity values for survival (LC50) and reproduction (EC50) in the different soils, expressed as $\mathrm{g}$ of sludge $\mathrm{kg}^{-1}$, together with its 95\% confidence intervals enclosed in parentheses (see Table 1 for soil abbreviations).

\begin{tabular}{|c|c|c|}
\hline Soil & LC50 $\left(\mathrm{g} \mathrm{kg}^{-1}\right)$ & EC50 $\left(\mathrm{g} \mathrm{kg}^{-1}\right)$ \\
\hline OECD & $32.0(28.9,35.2)$ & $2.7(2.0,3.4)$ \\
\hline CAM & $90.7(82.8,99.3)$ & $13.3(11.4,15.5)$ \\
\hline COLL & $46.6(45.3,48.0)$ & $23.9(21.7,26.4)$ \\
\hline GAN & $20.7(18.1,23.4)$ & $5.0(4.6,5.5)$ \\
\hline GRA & $35.7(29.6,42.6)$ & $8.7(7.7,9.8)$ \\
\hline POR & $57.3(51.6,63.5)$ & $15.6(13.8,17.6)$ \\
\hline PRA2 & $29.0(25.2,33.2)$ & $10.7(9.3,12.2)$ \\
\hline RIU & $33.2(29.9,36.8)$ & $17.1(15.3,19.0)$ \\
\hline STA & $91.7(87.0,96.7)$ & $47.2(44.3,50.2)$ \\
\hline VALL & $84.7(58.5,120.8)$ & $36.1(27.5,46.7)$ \\
\hline
\end{tabular}


Table 4. Pearson's correlation coefficients between the sludge concentration, $\mathrm{pH}$, electrical conductivity and water soluble ions in soil-sludge mixtures; * $\mathrm{p}<0.05$, ** $\mathrm{p}<0.001 ; \mathrm{n}=90$.

\begin{tabular}{|c|c|c|c|c|c|c|c|c|}
\hline & $\begin{array}{c}\text { Sludge } \\
\text { concentration }\end{array}$ & $\mathbf{p H}$ & $\mathbf{E C}$ & Chloride & Nitrite & Nitrate & Phosphate & Sulphate \\
\hline $\mathbf{p H}$ & $0.238^{*}$ & & & & & & & \\
\hline EC & $0.901^{* *}$ & $0.417^{* *}$ & & & & & & \\
\hline Chloride & $0.906^{* *}$ & 0.139 & $0.795^{* *}$ & & & & & \\
\hline Nitrite & -0.040 & 0.166 & 0.060 & -0.055 & & & & \\
\hline Nitrate & $-0.240^{*}$ & 0.166 & -0.038 & -0.183 & 0.118 & & & \\
\hline Phosphate & $0.542^{* *}$ & -0.037 & $0.519^{* *}$ & $0.727^{* *}$ & -0.028 & -0.150 & & \\
\hline Sulphate & $0.827^{* *}$ & 0.085 & $0.702^{* *}$ & $0.920^{* *}$ & 0.006 & -0.084 & $0.712^{* *}$ & \\
\hline Ammonium & $0.928^{* *}$ & $0.293^{* *}$ & $0.892^{* *}$ & $0.819^{* *}$ & -0.045 & $-0.263^{*}$ & $0.571^{* *}$ & $0.715^{* *}$ \\
\hline
\end{tabular}


Table 5. GLM parameters and significance of the model describing the effects on collembolans survival and reproduction; * $\mathrm{p}<0.05,{ }^{* *} \mathrm{p}<0.001 ; \mathrm{n}=90$.

\begin{tabular}{|c|c|c|c|c|c|}
\hline Endpoint & & Estimate & Std. Error & t value & $\operatorname{Pr}(>|\mathbf{t}|)$ \\
\hline \multirow{10}{*}{ Survival } & Intercept & 4.5998336 & 0.0513184 & 89.633 & $<2 \mathrm{e}-16 * *$ \\
\hline & Ammonium & -0.0016995 & -0.0001831 & -9.284 & $<2.19 \mathrm{e}-14 * *$ \\
\hline & Phosphate & -0.0007183 & 0.0004039 & -1.778 & 0.0791 \\
\hline & C & 0.0356326 & 0.0145998 & 2.441 & $0.0168 *$ \\
\hline & & & & & \\
\hline & $\begin{array}{l}\text { Degrees of } \\
\text { freedom }\end{array}$ & 84 & & & \\
\hline & Null deviance & 2123 & & & \\
\hline & $\begin{array}{l}\text { Residual } \\
\text { deviance }\end{array}$ & 587.7 & & & \\
\hline & $\mathbf{R}^{2}$ & 0.723 & & & \\
\hline & AIC & 1119 & & & \\
\hline \multirow{13}{*}{ Reproduction } & Intercept & 5.7320865 & 0.3812798 & 15.034 & $<2 \mathrm{e}-16 * *$ \\
\hline & Ammonium & -0.0049192 & 0.0007843 & -6.272 & $2.83 \mathrm{e}-08 * *$ \\
\hline & Phosphate & -0.0045712 & 0.0015389 & -2.971 & $0.00411^{* *}$ \\
\hline & Nitrite & -0.0026664 & 0.0011126 & -2.396 & $0.01931^{*}$ \\
\hline & C & 0.0495936 & 0.023998 & 2.066 & $0.04260 *$ \\
\hline & $\mathbf{p H}_{\text {soil }}$ & -0.1298969 & 0.0505408 & -2.570 & $0.01236^{*}$ \\
\hline & $\mathrm{C} / \mathrm{N}$ & -0.0070324 & 0.0024145 & -2.913 & $0.00485 * *$ \\
\hline & & & & & \\
\hline & $\begin{array}{c}\text { Degrees of } \\
\text { freedom }\end{array}$ & 74 & & & \\
\hline & Null deviance & 3285 & & & \\
\hline & $\begin{array}{l}\text { Residual } \\
\text { deviance }\end{array}$ & 928.5 & & & \\
\hline & $\mathbf{R}^{2}$ & 0.717 & & & \\
\hline & AIC & 1508 & & & \\
\hline
\end{tabular}


Figure 1
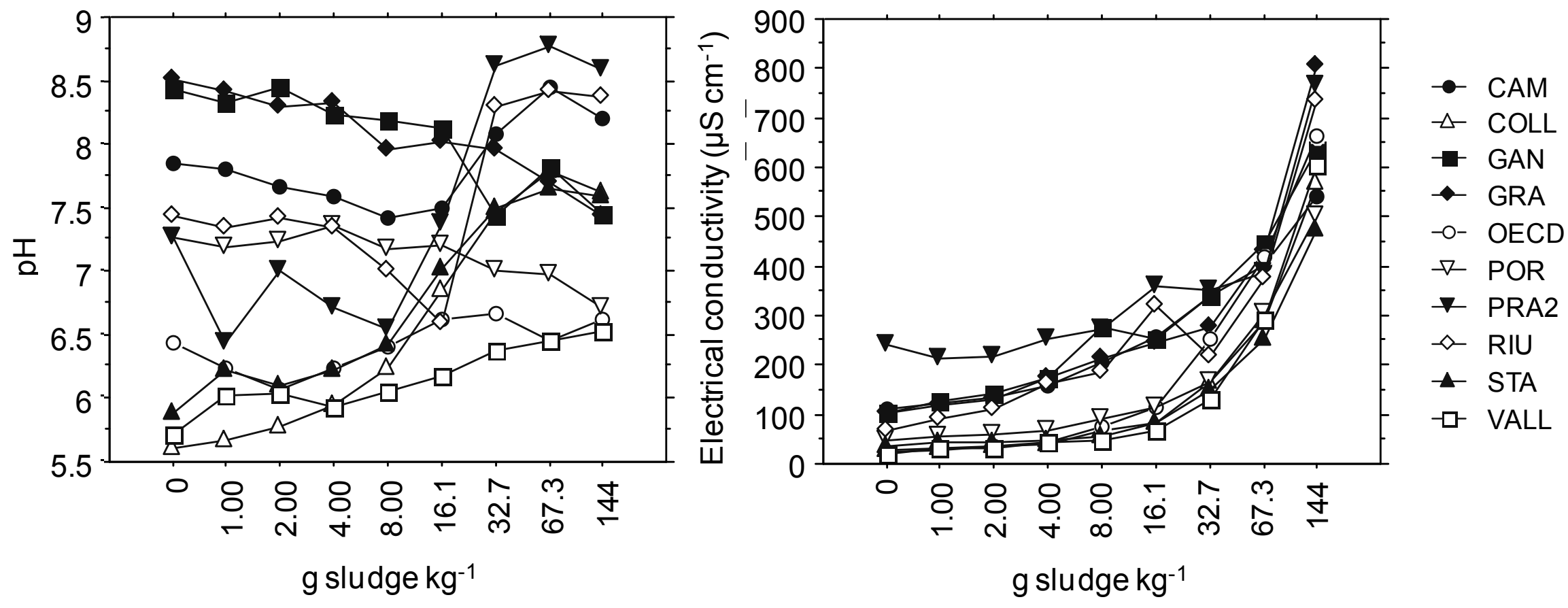
Figure 2
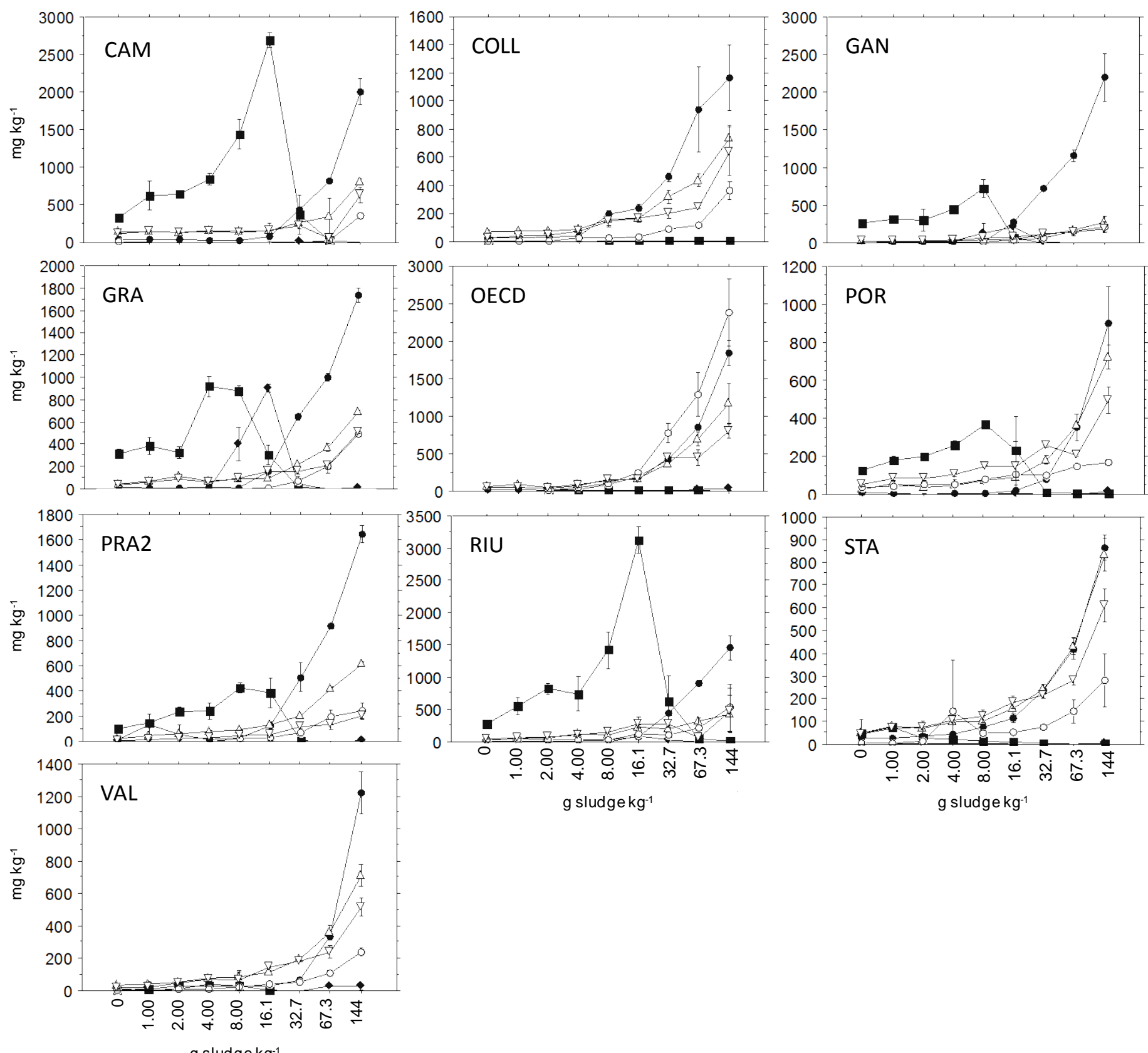

g sludge $\mathrm{kg}^{-1}$

g sludge $\mathrm{kg}^{-1}$

Ammonium

$-\triangle$ Chloride

- Nitrate

- Nitrite

-o- Phosphate

$\checkmark$ Sulfate 